\title{
Pemodelan Efisiensi Bank di Indonesia: Perbandingan antara Bank Syariah dan Bank Konvensional
}

\author{
Ar Royyan Ramly, Abdul Hakim \\ Universitas Serambi Mekkah, Universitas Islam Indonesia \\ royleesama@gmail.com, Abdulhakim@uii.ac.id
}

\begin{abstract}
This study aims to analyze the efficiency comparison between Islamic banks and conventional banks in Indonesia in 2012-2014. The method used in this study is non-parametric approach with data envelopment analysis (DEA) and Panel data regression whereas input and output variables are treated in intermediary function. To measure the efficiency level of Islamic banks and conventional banks the independent sample $t$ test is used. The result of the study shows that there is significant difference of efficiency between Islamic banking and conventional banking in 2012-2014. The empirical factors that affect Islamic banks and Conventional banks efficiency are ROA, CAR, and FDR variables. On the other hand, NPF results insignificantly and affects negatively towards Islamic banks efficiency. Lastly, ROA, NPL, LDR, and CAR had significantly affected Conventional banks efficiency.
\end{abstract}

Keywords: eficiency, data envelopment analysis, Islamic banks, conventional banks

\begin{abstract}
Abstrak
Penelitian ini bertujuan menganalisis perbandingan tingkat efisiensi bank syariah dengan bank konvensional di Indonesia Tahun 2012-2014. Metode yang digunakan dalam penelitian ini menggunakan pendekatan non-parametrik data envelopment analysis (DEA), dan Panel data regresi, dengan menggunakan variabel input dan output pada pendekatan intermediasi. Untuk membandingkan tingkat efisiensi bank syariah dan bank konvensional menggunakan $u j i$ beda independent sample $t$ test. Hasil penelitian ini menunjukkan terdapat perbedaan efisiensi antara bank syariah dan bank konvensional di Indonesia pada tahun 2012-2014. Hasil empiris faktor-faktor yang mempengaruhi efisiensi bank syariah dan bank konvensional ialah variabel ROA, CAR, dan FDR berpengaruh terhadap efisiensi bank syariah. Sedangkan variabel NPF berpengaruh negatif dan tidak signifikan terhadap efisiensi bank syariah. Kemudian variabel ROA, NPL, LDR, dan CAR berpengaruh signifikan terhadap efisiensi Bank Konvensional.
\end{abstract}

Kata Kunci: efisiensi, data envelopment analysis, bank syariah, bank konvensional

Diterima: 27 Februari 2017; Direvisi: 27 Maret 2017; Disetujui: 24 April 2017 


\section{PENDAHULUAN}

Krisis ekonomi Tahun 1997 yang melanda Indonesia, sehingga bank-bank swasta banyak terkena likuidasi, yang disebabkan oleh faktor diantaranya kredit macet. Pada tahun 1997 terdapat 7 bank pemerintah dan menyusut menjadi 5 bank pemerintah sejak tahun 1997 hingga 2001, jumlah dana yang dimiliki pada tahun 1997 sebesar Rp 153.266 miliar menurun hingga Rp 117.104 miliar pada tahun 2001. Sedangkan bank swasta dari 27 jumlah bank pada tahun 1991 menjadi 26 bank hingga tahun 2001, juga bank asing saat itu berjumlah 144 turun menjadi 80 bank asing yang ada di Indonesia (Huri \& Susilowati, 2004).

Pemerintah memberikan dukungan terhadap eksistensi perbankan syariah di Indonesia. Hal ini terbukti dengan diubahnya Undang-undang Nomor 7 Tahun 1992 menjadi Undang-undang Nomor 10 Tahun 1998 tentang perbankan Indonesia. Selain itu, pemerintah juga telah mengeluarkan regulasi terbaru yang mengatur secara khusus mengenai Perbankan Syariah melalui Undang-undang Nomor 21 Tahun 2008 (Pratikto \& Sugianto, 2011).

Semenjak dikeluarkannya Undang-undang Nomor 10 Tahun 1998 yang memperbolehkan bank umum konvensional beroperasi dengan menerapkan prinsip syariah atau melakukan operasional secara syariah dan konvensional (dual banking system). Pertumbuhan bank syariah mengalami akselerasi yang signifikan, dikarenakan unit syariah dapat menawarkan produk-produk perbankan syariah yang terpisah (Huda \& Nasution, 2014).

Namun salah satu aspek penting dalam perkembangan ini ialah kompetisi (persaingan) antara bank syariah dan bank konvensional. Tidak hanya itu sesama bank syariah juga mengalami persaingan yang ketat. Efisiensi menjadi hambatan bagi perbankan baik bank syariah maupun bank konvensional dalam bersaing. Apabila suatu bank menjadi efisien dalam kinerjanya, maka bank tersebut akan selalu stabil dalam menjalankan operasional dan pengembalian jangka panjang terhadap nasabah. Mengingat lembaga keuangan seperti perbankan merupakan lembaga yang sangat beresiko dan sensitif terhadap perkembangan ekonomi suatu Negara, karena perbankan menjalankan fungsi perantara (intermediasi).

Fungsi utama perbankan ialah sebagai lembaga intermediasi yaitu proses menghimpun dana dari, rumah tangga, pemerintah, dan sektor usaha untuk 
kemudian disalurkan kepada yang membutuhkan. Fungsi ini muncul disebabkan mahalnya biaya monitoring, biaya likuiditas dan risiko harga (price risk) karena adanya asymetric information antara pemilik dana dengan pengguna dana, sehingga membutuhkan pihak intermediary yang mampu mengakomodir dana kedua belah pihak (Siringoringo, 2012).

Fungsi inilah yang membuat lembaga keuangan seperti perbankan memiliki hubungan erat dengan sektor riil dan pengaruh tumbuhnya perekonomian dalam suatu Negara. Juga terkait dengan stabilisasi lembaga perbankan, sehingga berpengaruh pada sisi risiko likuiditas, risiko kredit dan risiko pembiayaan lain. Menyebabkan kegagalan perbankan akan berdampak sistemik bagi perekonomian Negara. Oleh karena itu pemerintah perlu menjaga dan mengawasi kesehatan bank. Sehingga sebuah bank harus menjaga kinerjanya agar dapat beroperasi secara optimal. Terlebih lagi saat ini bank syariah harus bersaing dengan bank-bank konvensional dengan perkembangan yang lebih pesat dari sebelumnya. Salah satu faktor yang diperhatikan ialah kinerja keuangan bank. Ini dapat diketahui melalui laporan keuangan bank dengan menghitung rasio. Sehingga kita bisa menganalisis kinerja perbankan secara sehat dan optimal (Ningsih, 2012).

Efisiensi menjadi salah satu parameter kinerja perbankan yang secara teoritis mendasari seluruh kinerja perusahan. Kemampuan memaksimalkan input yang tersedia untuk menghasilkan output yang tinggi merupakan ukuran kinerja yang diharapkan. Pada perbankan maka kondisi bagaimana mendapatkan input yang ada dengan meminimalkan tingkat input. Untuk melihat ketidakefesiensi sebuah perbankan dapat di identifikasi tingkat output dan inputnya dengan menganalisa lebih jauh faktor-faktor penyebabnya (Sarjono, 2008).

Sebab terdapat hubungan antara sektor keuangan dengan stabilitas perekonomian Negara. Efisiensi pada sektor keuangan menunjukkan pertumbuhan perekonomian. Bank Indonesia dalam kebijakannya menargetkan pada tiga koridor utama yaitu: Pertama, pemeliharaan stabilitas sistem keuangan. Kedua, penguatan ketahanan dan daya saing perbankan. Ketiga, penguatan fungsi intermediasi. Sementara untuk perbankan syariah, prospek ekonomi dan kebijakan tersebut diharapkan akan semakin mendorong pertumbuhan industri ke depan khususnya 
melalui potensi pasar yang masih besar yang belum tergarap sepenuhnya seiring dengan membaiknya pendapatan per-kapita masyarakat, koordinasi yang lebih baik antar stakeholders dalam pengembangan keuangan syariah dan kuatnya sektor konsumsi domestik serta keberhasilan program promosi dan edukasi publik perbankan syariah (Bank Indonesia, 2013).

Kebanyakan studi efisiensi hanya melakukan pengukuran kinerja efisiensi teknis, sementara penelitian yang melakukan analisis terhadap faktorfaktor yang mempengaruhi efisiensi teknis masih jarang terutama untuk bank syariah, dan juga model pengukuran efisiensi pada bank syariah belum banyak ditemukan seperti pengukuran efisiensi pada perusahaan dan bank konvensional yang berbasis input dan output yang dianggap sama. Sedangkan terdapat perbedaan operasional antara bank syariah dan bank konvensional dan melihat variabelvariabel yang adil untuk dibandingkan dengan bank konvensional. Fokus penelitian ini ialah menggali lebih dalam variabel-variabel yang digunakan dan hendak menemukan model yang cocok untuk pengukuran efisiensi bank syariah sehingga mudah dibedakan pendekatan yang dipakai untuk perbandingannya.

Oleh karena itu penelitian ini bermaksud meneliti tingkat perbandingan efisiensi bank syariah dengan bank konvensional yang ada di Indonesia dengan menggunakan software Data Envelopment Analysis (DEA). Selanjutnya peneliti menentukan variabel output dan input lembaga atau organisasi melalui pendekatan intermediasi, karena mengingat fungsi perbankan sebagai lembaga intermediasi dari pihak memiliki dana kepada pihak yang membutuhkan dana. Selanjutnya melakukan perbandingan antara kedua efisiensi bank syariah dan bank konvensional Kemudian menganalisa faktor-faktor (determinant) yang mempengaruhi tingkat efisiensi perbankan secara internal dengan menggunakan alat analisis data panel.

Demikian penelitian ini dapat menjadi konstribusi positif bagi kepentingan akademik dan berdampak bagi lembaga keuangan yang ada di Indonesia untuk meningkatkan kinerja efisiensi perbankan untuk menunjang kesehatan lembaga keuangan. Sehingga masyarakat mendapatkan kepercayaan (trust) dan kenyamanan menitipkan dananya di perbankan syariah maupun konvensional. 


\section{METODE}

Metode yang dipakai dalam penelitian ini dalam mengukur kinerja efisiensi teknis menggunakan Data Envelopment Analysis (DEA). DEA mengukur perbandingan antara input dan ouput yang dimiliki perbankan, pendekatan yang digunakan ialah pendekatan intermediasi dalam mengukur input dan output. Sampel yang diteliti dalam penelitian ini sebanyak 20 Bank Syariah dan 20 bank konvensional pada periode 2012-2014. Variabel-variabel yang digunakan ialah variabel input terdiri atas Total Simpanan (DPK), Biaya Tenaga Kerja (price of labor), dan jumlah aset (total asset). Sedangkan variabel output terdiri dari: Total Pembiayaan (Total Cost), dan total pendapatan operasional. Kemudian untuk melihat perbandingan antara bank syariah dengan bank konvensional Tahun 2012-2014 maka penulis menggunakan metode Independent sample $t$ test. Hasil tersebut selanjutnya dikelompokkan dalam perbandingan efisiensi bank syariah dan bank konvensional.

Untuk melihat faktor yang mempengaruhi kinerja efisiensi menggunakan Variabel independen (bebas/tidak terikat) pada penelitian ini terdiri atas rasio keuangan pada bank syariah dan bank konvensional seperti ROA, CAR, LDR/FDR, NPL/NPF. Variabel ini digunakan untuk mengukur faktor-faktor yang mempengaruhi kinerja efisiensi perbankan. Sedangkan skala efisiensi perbankan yang diukur dengan metode DEA digunakan sebagai variabel dependen yang dianggap sebagai skala efisiensi keseluruhan bank yang diukur dengan input dan output tertentu. Pada penelitian ini menggunakan model efek tetap (fixed effect model), karena data yang digunakan merupakan data panel yang terdiri dari data cross section dan time series dengan jumlah individu yang beragam dan waktu hanya diambil dalam kurun 3 tahun.

\section{HASIL DAN PEMBAHASAN}

\section{Hasil}

Hasil pengukuran Data Envelopment Analysis (DEA) dengan pendekatan constant return to scale (CRS) dan variable return to scale (VRS) pada bank syariah periode 2012-2014 (lihat Tabel 1). Pada Bank Syariah terdapat 9 DMU yang dinyatakan memiliki skala efisiensi sempurna, artinya DMU yang memiliki skala 1 
sampai 100 dianggap efisien dan sebaliknya. Bank-bank yang memiliki efisiensi sempurna ialah seperti. Bank Mega Syariah memperoleh skala 100\% (efisien), Maybank Syariah sebesar 100\%, Bank Bukopin Syariah 100\%, BJB Syariah 100\% , Bank Danamon Syariah 100\%, Bank Sinarmas Syariah pada asumsi CRS dan VRS dinyatakan tidak efisien, setelah dihitung dengan asumsi SE, maka memperoleh skala 100\% (efisien), BII Syariah memiliki efisien 100\%. Terakhir Bank Aceh Syariah memperoleh skala efisiensi sempurna sebesar 100\% (efisien) dan BTPN Syariah juga memperoleh efisiensi sebesar 100\% (efisien). Hosen dan Rahmawati (2016) menunjukkan pula bahwa Bank Mega Syariah mampu mencapai tingkat efisiensi tertinggi dibandingkan dengan bank umum syariah lainnya.

Tabel 1. Asumsi CRS Dan VRS Kinerja Efisiensi Bank Syariah

\begin{tabular}{clrr}
\hline No & \multicolumn{1}{c}{ DMU } & CRS Mean & VRS Mean \\
\hline 1 & BRI Syariah & $81.62 \%$ & $91.73 \%$ \\
2 & BNI Syariah & $90.64 \%$ & $100 \%$ \\
3 & BSM & $77.69 \%$ & $100 \%$ \\
4 & Bank Muamalat & $52.39 \%$ & $95.88 \%$ \\
5 & Bank Mega Syariah & $100 \%$ & $100 \%$ \\
6 & MayBank Syariah & $99.16 \%$ & $99.34 \%$ \\
7 & Bank Victoria Syariah & $60.60 \%$ & $63.27 \%$ \\
8 & BCA Syariah & $38.75 \%$ & $43.40 \%$ \\
9 & Bank Syariah Bukopin & $92.16 \%$ & $92.36 \%$ \\
10 & Bank Panin Syariah & $49.85 \%$ & $50.85 \%$ \\
11 & BJB Syariah & $58.24 \%$ & $67.97 \%$ \\
12 & Bank Danamon Syariah & $83.27 \%$ & $86.89 \%$ \\
13 & Bank Sinarmas Syariah & $100 \%$ & $100 \%$ \\
14 & BTN Syariah & $77.79 \%$ & $100 \%$ \\
15 & BII Syariah & $100 \%$ & $100 \%$ \\
16 & Bank Permata Syariah & $60.26 \%$ & $100 \%$ \\
17 & Bank DKI Syariah & $77.61 \%$ & $80.02 \%$ \\
18 & Bank DIY Syariah & $73.43 \%$ & $100 \%$ \\
19 & Bank Aceh Syariah & $100 \%$ & $100 \%$ \\
20 & BTPN Syariah & $100 \%$ & $100 \%$ \\
\hline
\end{tabular}

Selain itu terdapat DMU (bank Syariah) yang dinyatakan tidak efisien (inefisiensi) setelah dihitung seperti bank DIY syariah, pada asumsi VRS justru terlihat efisiensi, setelah dihitung dengan asumsi SE, maka Bank DIY syariah memperoleh efisiensi relatif sebesar 73\%. Kemudian hasil analisis skala efisiensi untuk Bank Syariah rata-rata pada tahun 2012-2014 terdapat 11 DMU (bank 
syariah) yang dinyatakan inefisien secara skala efisiensi gabungan CRS dan VRS. Masing-masing DMU (bank syariah) yang memperoleh hasil inefisien.

Seperti BRI Syariah sebelumnya pada kedua pendekatan CRS maupun VRS memiliki efisiensi rendah, maka asumsi skala efisiensi setelah dihitung memperoleh skala efisiensi sebesar 85\%, BNI Syariah memperoleh 91\%. Sama halnya Bank Muamalat hanya memperoleh skala efisiensi SE sebesar 55\%, BSM sebesar 78\% (inefisien), Bank Victoria Syariah sebesar 91\%, BCA Syariah 90\%, (BTN) syariah sebesar 78\% (inefisien), Bank Panin Syariah memperoleh 98\% (inefisien), Bank Permata Syariah 60\%. Terakhir bank DKI syariah memperoleh 97\% (inefisien).

Sedangkan hasil pengukuran Data Envelopment Analysis (DEA) dengan pendekatan CRS dan VRS pada bank konvensional periode 2012-2014 menunjukkan hasil sebagai berikut:

Tabel 2. Asumsi CRS Dan VRS Kinerja Efisiensi Bank Konvensional

\begin{tabular}{clcc}
\hline No & \multicolumn{1}{c}{ DMU } & CRS Mean & VRS Mean \\
\hline 1 & BRI & $98.23 \%$ & $100 \%$ \\
2 & BNI & $88.12 \%$ & $93.46 \%$ \\
3 & Bank Mandiri & $100 \%$ & $100 \%$ \\
4 & Mutiara Bank & $100 \%$ & $100 \%$ \\
5 & BTN & $99.61 \%$ & $100 \%$ \\
6 & BII & $91.55 \%$ & $93.73 \%$ \\
7 & Bank Central Asia & $93.24 \%$ & $97.36 \%$ \\
8 & Bank Pundi & $98.74 \%$ & $100 \%$ \\
9 & Bank Mega & $56.77 \%$ & $58.42 \%$ \\
10 & Bank Victoria & $99.81 \%$ & $100 \%$ \\
11 & BTPN & $100 \%$ & $100 \%$ \\
12 & Bank Sinarmas & $80.45 \%$ & $81.63 \%$ \\
13 & Bank Danamon & $97.58 \%$ & $100 \%$ \\
14 & Bank Bukopin & $92.99 \%$ & $95.36 \%$ \\
15 & Panin Bank & $100 \%$ & $100 \%$ \\
16 & Bank Permata & $88.20 \%$ & $91.39 \%$ \\
17 & Bank DIY & $79.55 \%$ & $100 \%$ \\
18 & BJB & $74.31 \%$ & $74.41 \%$ \\
19 & Bank Aceh & $81.98 \%$ & $83.10 \%$ \\
20 & Bank DKI & $69.70 \%$ & $70.53 \%$ \\
\hline
\end{tabular}

Sumber: DEA excel

Lebih lanjut hasil analisis skala efisiensi rata-rata (SE) pada DMU (bank syariah) dapat dibandingkan dengan skala efisiensi DMU (bank Konvensional). Hasil 
skala efisiensi yang diperoleh DMU (bank konvensional) terlihat lebih sedikit daripada DMU (bank syariah). Bank konvensional memperoleh hasil efisiensi sebanyak 7 DMU (bank konvensional), secara kuantitas (unit-unit) memang lebih banyak DMU (bank syariah) yang dinyatakan efektif. Namun agar lebih objektif ini dapat diukur kembali perbandingan antara efisiensi bank syariah dan bank konvensional.

Dari 20 DMU (bank konvensional) terdapat 7 DMU (bank konvensional) yang menghasilkan skala efisiensi 100\% atau dinyatakan efisien. Diantara bank konevensional yang memperoleh efisiensi SE sempurna ialah Bank Mandiri memperoleh skala 100\% (efisien), Bank Mutiara sebesar 100\% (efisien), BTN sebesar 100\%, BCA 100\%, Bank Victoria sebesar 100\%, BTPN 100\%, dan terakhir Panin Bank sebesar 100\% (efisien).

Kemudian dari 20 DMU (Bank Konvensional) terdapat hasil bank-bank yang dianggap kurang efisien dalam kinerjanya (inefisien), diantara bank tersebut ialah seperti BRI mendapatkan skala efisiensi 98\% (inefisien), BNI sebesar 94\% (inefisien), BII sebesar 96\%, Bank Pundi sebesar 97\% (inefisien), Bank Mega sebesar 97\% (inefisien), Bank Danamon sebesar 99\% (inefisien), Bank Sinarmas 94\%, BJB sebesar 99\%. Bank Bukopin sebesar 98\% (inefisien), Bank Permata sebesar 97\%, Bank DIY sebesar 80\% (inefisien), Bank Aceh sebesar 97\% (inefisien), dan terakhir Bank DKI skala efisiensi sebesar 99\% (inefisien).

Kemudian hasil pengukuran Data Envelopment Analysis (DEA) dengan pendekatan Scale efficiency (SE) pada bank konvensional periode 2012-2014 menunjukkan hasil sebagaimana terlihat pada Tabel 3.

Hasil perbandingan efisiensi pada bank syariah dan bank konvensional periode 2012-2014 dengan mengunakan independent sample t test menunjukkan hasil rata-rata ketiga skala efisiensi (SE) Bank Syariah dan Bank Konvensional periode Tahun 2012-2014 dapat disimpulkan $\mathrm{H}_{\mathrm{a}}$ diterima, artinya terdapat perbedaan antara efisiensi Bank Syariah dan bank konvensional di Indonesia Tahun 2012-2014.

Hasil penelitian ini bertolak belakang dengan hasil penelitian sebelumnya. Hanya pada Tahun 2014 yang sesuai dengan penelitian dilakukan oleh Setiawan (2013), dengan hasil tidak terdapat perbedaan signifikan antara efisiensi Bank 
Syariah dan Bank Konvensional periode 2008-2012, dengan melihat $\mathrm{t}$ hitung $<$ dari $\mathrm{t}$ tabel dengan P-value=0.125. Selanjutnya hasil penelitian Pratikto \& Sugianto (2011), dengan hasil tidak terdapat perbedaan signifikan antara efisiensi bank syariah setelah dan sesudah krisis pada pendekatan DEA-CRS dan DEA-VRS.

Tabel 3. Hasil Pengukuran Scale Efficiency

\begin{tabular}{lclc}
\hline \multicolumn{1}{c}{ Bank Syariah } & Mean SE & \multicolumn{1}{c}{ Bank Konvensional } & Mean SE \\
\hline BRI Syariah & 0.85 & Bank Rakyat Indonesia & 0.98 \\
BNI Syariah & 0.91 & Bank Nasional Indonesia & 0.94 \\
BSM & 0.78 & Bank Mandiri & 1.00 \\
Bank Muamalat & 0.55 & Mutiara Bank & 1.00 \\
Bank Mega Syariah & 1.00 & BTN & 1.00 \\
Maybank Syariah & 1.00 & BII & 0.96 \\
Bank Victoria Syariah & 0.91 & Bank Central Asia & 1.00 \\
BCA Syariah & 0.90 & Bank Pundi & 0.99 \\
Bank Syariah Bukopin & 1.00 & Bank Mega & 0.97 \\
Bank Panin Syariah & 0.98 & Bank Victoria & 1.00 \\
BJB Syariah & 1.00 & BTPN & 1.00 \\
Bank Danamon Syariah & 1.00 & Bank Sinarmas & 0.94 \\
Bank Sinarmas Syariah & 1.00 & Bank Danamon & 0.99 \\
BTN Syariah & 0.78 & Bank Bukopin & 0.98 \\
BII Syariah & 1.00 & Panin Bank & 1.00 \\
Bank Permata Syariah & 0.60 & Bank Permata & 0.97 \\
Bank DKI Syariah & 0.97 & Bank DIY & 0.80 \\
Bank DIY Syariah & 0.73 & Bank Jabar Banten & 0.99 \\
Bank Aceh Syariah & 1.00 & Bank Aceh & 0.97 \\
BTPN Syariah & 1.00 & Bank DKI & 0.99 \\
\hline
\end{tabular}

Penelitian yang dilakukan oleh Fauzi (2013), menunjukkan hasil tidak terdapat perbedaan signifikan antara BUS dan BUK dengan signifikansi SE (0.796>a) sehingga $\mathrm{H}_{0}$ diterima. Kemudian penelitian Shahid, dkk (2010), menyebutkan hasil tidak ada perbedaan signifikan antara efisiensi skor rata-rata bank konvensional dan bank syariah. Terakhir penelitian Noor (2013), menunjukkan hasil tidak terdapat perbedaan signifikan antara efisiensi bank umum syariah dan bank umum konvesional pada pendekatan DEA-CRS dan pendekatan DEA-VRS.

Selanjutnya untuk menganalisis faktor-fator yang mempengaruhi kinerja efisiensi ditunjukkan pada hasil regresi Fixed Effect Model (FEM) yang diukur menggunakan eviews 8.0 ditunjukkan pada Tabel 4. Hasil empiris menunjukkan 
bahwa faktor yang mempengaruhi kinerja efisiensi pada bank syariah ialah tingkat profitabilitas (diukur dengan ROA), rasio likuiditas (diukur dengan FDR), dan rasio kecukupan modal Sedangkan faktor yang mempengaruhi kinerja efisiensi pada bank konvensional ialah tingkat profitabilitas (diukur dengan ROA), tingkat pembiayaan bermasalah (diukur dengan NPL), rasio likuiditas (diukur dengan FDR), dan rasio kecukupan modal

Tabel 4. Hasil Regresi Faktor Yang Mempengaruhi Kinerja Efisiensi Bank Syariah dan Bank Konvensional

\begin{tabular}{ccccc}
\hline Variabel & t-Statistic & $\begin{array}{c}\text { Prob. Bank } \\
\text { Syariah }\end{array}$ & t-Statistic & $\begin{array}{c}\text { Prob.Bank } \\
\text { Konvensional }\end{array}$ \\
\hline C & -2.641141 & 0.0123 & 1.857364 & 0.0717 \\
LOG(ROA) & -5.980466 & 0.0000 & 4.272712 & 0.0001 \\
LOG(NPF)/NPL & -1.920170 & 0.0630 & -3.078824 & 0.0040 \\
LOG(FDR)/LDR & 3.019806 & 0.0047 & -3.389656 & 0.0017 \\
LOG(CAR) & -3.657145 & 0.0008 & 4.473596 & 0.0001 \\
\hline
\end{tabular}

Sumber: diolah dari Eviews 8.0

\section{Pembahasan}

Pendekatan intermediasi yang digunakan sesuai dengan penelitian yang lalu seperti penelitian yang dilakukan oleh, Setiawan (2012), Sari (2010), Pratikto \& Sugianto (2011), Firdaus \& Hosen (2013), Fauzi (2013) dan Huri \& Susilowati (2004). Adapun variabel dalam penelitian ini meliputi variabel input, total asset, total simpanan (DPK), dan biaya tenaga kerja. Variabel output yaitu total pembiayaan dan total pendapatan operasional.

Selanjutnya DEA memiliki dua pendekatan untuk mengukur tingkat efisiensi masing-masing perbankan yaitu, constant return to scale (CRS) dan variabel return to scale. Namun untuk keseluruhan efisiensi bank dapat dihitung dari perbandingan asumsi CRS dan VRS yang menghasilkan skala efisiensi (SE).

Hasil pengukuran efisiensi bank syariah pada Tahun 2012 dengan pendekatan CRS menunjukkan hanya 5 bank syariah yang tergolong efisien sempurna (BMS, BDS, BSS BIIS, dan BAS). Sedangkan pada Tahun 2013 jumlah bank syariah yang tergolong efisien sempurna meningkat sebanyak 6 bank. Kemudian pendekatan CRS pada tahun 2014 jumlah bank syariah yang efisien sebanyak 10 bank syariah. Namun secara rata-rata efisiensi pendekatan CRS untuk bank syariah 
hanya sebanyak 5 bank syariah yang efisien pada Tahun 2012-2014. Rata-rata efisiensi pada pendekatan CRS bank syariah lebih dominan dialami oleh unit usaha syariah (UUS) daripada Bank Umum syariah (BUS).

Walaupun demikian setiap tahun jumlah efisiensi bank syariah meningkat sangat pesat, dari 5 bank yang efisien menjadi 10 bank yang efisien pada pendekatan CRS. Kemudian pada pendekatan VRS bank syariah terdapat 8 bank syariah yang efisien pada Tahun 2012. Pada pendekatan VRS ini variabel lainnya dianggap tetap dan tidak mempengaruhi variabel lain. Pada Tahun 2013 bertambah sebanyak 11 bank syariah yang tergolong efisien. Kemudian pendekatan VRS untuk bank syariah pada pendekatan 2014 meningkat sebanyak 12 bank yang tergolong efisien sempurna. Sedangkan rata-rata bank syariah yang efisien pada pendekatan VRS ialah sebanyak 10 bank syariah yang tergolong efisien.

Dilihat dari keseluruhan efisiensi bank syariah pada Tahun 2012-2014, maka diperoleh rata-rata efisiensi bank syariah pada pendekatan skala efisiensi (SE) sebanyak 9 bank syariah yang tergolong efisien sempurna. Rata-rata yang mengalami efisiensi sempurna ini ialah bank umum syariah sedangkan unit usaha syariah juga masih tergolong baik walaupun dibawah efisiensi bank umum syariah (BUS). Hal ini dikarenakan bank umum syariah lebih mudah bersaing dengan bank lainnya, dibandingkan unit usaha syariah yang masih berada seatap dengan bank konvensional.

Rodoni, dkk (2017) dalam penelitian menunjukkan bahwa industri perbankan syariah di Indonesia cenderung kurang efisien dalam lima tahun terakhir dibandingkan dengan Malaysia dan Pakistan. Yulita dan Rizal (2016) menyebutkan bahwa terdapat beberapa faktor yang menyebabkan terjadinya inefisiensi pada bank syariah, yaitu dana pihak ketiga, total pembiayaan, aset tetap, dan biaya operasional Sedangkan pendapatan operasional masih menjadi variabel yang paling efisien bagi industri perbankan syariah di Indonesia.

Kemudian perkembangan efisiensi bank konvensional cukup beragam pada tahun 2012-2014. Dilihat dari pendekatan CRS pada Tahun 2012 jumlah bank konvensional yang efisien sebanyak 7 bank konvensional, lebih tinggi dibandingkan bank syariah. Selanjutnya pada Tahun 2013 jumlah efisiensi bank konvensional 
menurun menjadi 3 bank konvensional. Sedangkan pada Tahun 2014 jumlah efisiensi bank konvensional dengan pendekatan CRS mengalami efisien sebanyak 5 bank. Kalau dilihat dari rata-rata CRS hanya sebanyak 4 bank konvensional yang efisien. Sedankan pada pendekatan VRS untuk bank konvensional Tahun 2012 sebanyak 10 bank. Pada Tahun 2013 sebanyak 9 bank konvensional yang efisien. Pada tahun 2014 jumlah bank konvensional yang efisien bertambah sebanyak 10 bank. Kemudian rata-rata bank konvensional pada pendekatan VRS hanya sebanyak 10 bank konvensional yang efisien sempurna. Dilihat dari keseluruhan efisiensi Tahun 2012-2014 pada pendekatan SE jumlah bank konvensional yang efisien ialah sebanyak 7 bank konvensional yang efisien. Jumlah ini masih dibawah rata-rata efisiensi bank syariah. Hal ini dikarenakan bank konvensional masih belum optimal dalam mengelola dana pihak ketiga dan kredit dan terlalu besar cost of fund untuk operasional perbankan.

Kemudian setelah hasil skala efisiensi diperoleh dari 20 sampel bank syariah dan bank konvensional peneliti membandingkan efisiensi keduanya, dengan menggunakan uji beda independent sample t test. Hasil uji beda antara bank syariah dan bank konvensional Tahun 2012-2014, maka diperoleh hasil dari tahun 2012 menunjukkan terdapat perbedaan signifikan antara efisiensi bank syariah dan bank konvensional, dengan nilai probabilitas sig(2-tailed) sebesar 0.007, p-value lebih kecil dari $\alpha=0.05$ yang berarti $\mathrm{H}_{\mathrm{a}}$ diterima terdapat perbedaan signifikan antara efisiensi bank syariah dengan Bank Konvensional pada Tahun 2012. Hasil ini tidak sesuai dengan penelitian yang dilakukan oleh Shahid, dkk (2010), yang menyatakan tidak terdapat perbedaan singnifikan rata-rata bank syariah dan bank konvensional. Sedangkan pada Tahun 2013 hasil uji independen sample $t$ test menunjukkan hasil yang sama dengan probabilitas sig(2-tailed) sebesar 0.022 lebih kecil dari $\alpha=0.05$ artinya $\mathrm{H}_{\mathrm{a}}$ diterima terdapat perbedaan antara efisiensi Bank Syariah dan Bank Konvensional pada skala efisiensi (SE) pada Tahun 2013. Pada Tahun 2014 hasil uji independent sampel $t$ test menunjukkan probabilitas sig(2-tailed) sebesar 0.166 lebih besar dari $\alpha=0.05$, maka $\mathrm{H}_{0}$ diterima artinya tidak terdapat perbedaan signifikan antara efisiensi Bank Syariah dan Bank Konvensional pada Tahun 2014. Dengan demikian dari hasil rata-rata ketiga skala efisiensi (SE) Bank Syariah dan Bank Konvensional periode Tahun 2012-2014 dapat disimpulkan $\mathrm{H}_{\mathrm{a}}$ diterima, 
artinya terdapat perbedaan antara efisiensi Bank Syariah dan bank konvensional di Indonesia Tahun 2012-2014.

Hasil inpendent sampel $t$ test ini kontradiksi dengan hasil penelitian sebelumnya. Hanya pada Tahun 2014 yang sesuai dengan penelitian dilakukan oleh Setiawan (2012), Pratikto \& Sugianto (2011), Fauzi (2013), Shahid, dkk (2010), Noor (2013). Perbedaan ini dikarenakan terdapat beberapa variabel input dan output yang digunakan berbeda dari penelitian sebelumnya. Kemudian variasi hasil pengukuran DEA yang beragam dikarenakan perbedaan konsep operasional bank syariah dan bank konvensional berbeda.

Selanjutnya melihat hasil estimasi variabel ROA berpengaruh negatif dan signifikan terhadap efisiensi bank syariah. Hasil ini sesuai dengan penelitian Rahman \& Rosman (2013), Endri (2011), Ismail, dkk. (2013), Ilyana (2014), Firdaus \& Hosen (2013), dan Hassan (2005). Hassan (2005) menyebutkan ROA memiliki korelasi yang kuat antara efisiensi bank dengan profitabiltas bank syariah. Sedangkan Ismail, dkk (2013) menyatakan hasil yang serupa ROA berpengaruh positif terhadap efisiensi bank syariah secara skala efisiensi (SE). Maka dengan hasil di atas dapat dikatakan meskipun variabel return on asset berpengaruh negatif, semakin tinggi rasio ROA maka bank syariah semakin efisien.

Kemudian hasil regresi untuk bank konvensional variabel ROA berpengaruh positif dan signifikan terhadap efisiensi bank konvensional pada tahun 2012-2014. Hasil analisis pengaruh ROA pada bank konvensional sesuai dengan penelitian Soetanto \& Ricky (2011), yang menunjukkan ROA berpengaruh signifikan terhadap efisiensi bank konvensional di Indonesia, dikarenakan jumlah asset yang dimiliki oleh bank konvensional lebih besar dibandingkan dengan bank syariah.

Hasil estimasi NPF berpengaruh negatif tetapi tidak signifikan terhadap efisiensi bank syariah pada Tahun 2012-2014. Artinya NPF tidak berpengaruh terhadap efisiensi bank syariah di Indonesia. Ini bertolak belakang dengan hipotesis awal yang mensyaratkan NPF berpengaruh negatif dan signifikan terhadap efisiensi bank syariah. Kemudian hasil temuan untuk bank konvensional terhadap Non Peforming Loan (NPL) Maka menerima hipotesis bahwa NPL berpengaruh negatif 
dan signifikan terhadap efisiensi bank konvensional. Berarti rasio NPL mempengaruhi efisiensi bank konvensional pada Tahun 2012-2014. Hal ini disebabkan rasio NPL pada bank konvensional relatif lebih kecil dan beban resiko yang ditanggung oleh bank konvensional lebih rendah karena bank yang lebih besar akan mengeluarkan biaya jaminan, pengawasan untuk pembiayaan bermasalah.

Sedangkan rasio FDR bank syariah menunjukkan Financing Deposit Ratio (FDR) berpengaruh positif dan signifikan terhadap efisiensi bank syariah. Pembiaayaan yang disalurkan bank syariah tergolong tinggi dan meningkat pada Tahun 2012-2014, sehingga menyebabkan variabel FDR semakin optimal dan mempengaruhi efisiensi bank syariah secara positif dan signifikan. Kemudian hasil analisis Loan Deposit Ratio (LDR) berpengaruh negatif dan signifikan terhadap efisiensi bank konvensional di Indonesia. Dikarenakan negatif dan signifikan dapat dilihat dari potential improvement DEA rata-rata bank konvensional masih belum optimal dalam memberikan pembiayaan kepada pihak ketiga. Namun hasil analisis didapati LDR berpengaruh signifikan terhadap efisiensi bank konvensional di Indonesia periode 2012-2014.

Hasil empiris penelitian ini menunjukkan variabel CAR berpengaruh signifikan terhadap efisiensi bank syariah Tahun 2012-2014. Menerima hipotesis awal, maka semakin tinggi rasio CAR pada suatu bank maka semakin efisien pula bank tersebut. Dikarenakan bank yang memiliki modal yang besar akan mampu menjaga stabilitas kinerja (performance) secara keseluruhan. Hasil penelitian ini sesuai dengan penelitian Ilyana (2014), Endri (2011) dan Muizuddin \& Iznurhadi (2012) yang tidak sesuai dengan hasil penelitian ini, hasil penelitiannya menunjukkan ROA tidak berpengaruh positif terhadap efisiensi perbankan syariah di Indonesia. Karena market share bank syariah relatif kecil untuk skala bank syariah, maka akan sulit untuk bank syariah memperoleh keuntungan yang besar, kosekuensinya apabila ROA tidak meningkat, maka bank syariah akan sulit untuk menjadi efisien.

Selanjutnya hasil analisis variabel CAR untuk bank konvensional di Indonesia tahun 2012-2014. Variabel CAR berpengaruh positif dan signifikan terhadap efisiensi bank konvensional di Indonesia. Hasil temuan ini konsisten dengan hasil penelitian sebelumnya yang dilakukan oleh Perwitaningtyas (2014). 
Namun kebanyakan penelitian menganggap variabel CAR tidak berpengaruh atau tidak mempunyai hubungan dengan efisiensi perbankan. Seperti Soetanto \& Ricky (2011), menunjukkan bahwa tingkat kesehatan bank tidak berpegaruh terhadap efisiensi yang menunjukan Capital Adequacy Ratio (CAR) yang dimiliki oleh bank hanya digunakan oleh bank untuk memenuhi aturan kebijakan modal minimum sehingga tidak berdampak kepada efisiensi bank.

\section{SIMPULAN}

Hasil estimasi dengan menggunakan DEA serta perbandingan efisiensi kinerja bank syariah dan bank konvensional dan mengukur faktor yang mempengaruhi kinerja efisiensi. Membuktikan Pendekatan scale efficiency (SE) dapat disimpulkan bahwa terdapat 9 bank syariah yang tergolong efisien dan7 bank konvensional yang tergolong efisien tahun 2012-2014. Hasil independen sampel $t$ test diperoleh, terdapat perbedaan $\left(\mathrm{H}_{\mathrm{a}}\right.$ diterima $)$ antara tingkat efisiensi bank syariah dan bank konvensional dengan asumsi SE periode 2012-2014, rata-rata perbandingan disimpulkan terdapat perbedaan efisiensi bank syariah dan bank konvensional tahun 2012-2014.

Efisiensi Bank Syariah 2012-2014 dengan variabel ROA, NPF, FDR, dan CAR. Maka dapat disimpulkan variabel ROA berpengaruh signifikan sebesar 0.0000, variabel FDR berpengaruh signifikan sebesar 0.0047, variabel CAR berpengaruh signifikan sebesar 0.0008. Sedangkan variabel NPF tidak berpengaruh signifikan dengan nilai 0.0630. sedangkan Efisiensi bank konvensional dapat disimpulkan variabel ROA berpengaruh signifikan sebesar 0.0001, variabel NPL berpengaruh signifikan sebesar 0.0040, variabel LDR berpengaruh signifikan sebesar 0.0017, dan variabel CAR berpengaruh positif dan signifikan sebesar 0.0001 terhadap efisiensi bank konvensional di Indonesia tahun 2012-2014.

\section{PUSTAKA ACUAN}

Ahmad, N.H \& Noor, M.A.N.M (2011). The Determinants Efficiency and Profitability of World Islamic Banks. Hong Kong: International Conference on Ebusiness, Management and Economics IPEDR vol.3. IACSIT Press, Hong Kong, 228-233. 
Bank Indonesia. (2013). Laporan Perkembangan Perbankan Syariah. Jakarta: Bank Indonesia.

Endri. (2011). Evaluasi Efisiensi Teknis Perbankan Syariah di Indonesia: Aplikasi Two-Stage Data Envelopment Analysis. Forum Riset Perbankan Syariah. Ikatan Ahli Ekonomi Islam dan Bank Indonesia.

Fauzi, M.R. (2013). Analisis Perbandingan Efisiensi Bank Umum Syariah dan Bank Umum Konvensional Dengan Metode Data Envelopment Analysis (DEA), (Studi Kasus BRI dan BSM pada Tahun 2007-2011). (Skripsi Tidak Dipublikasikan). Yogyakarta: UIN Sunan Kalijaga.

Firdaus, M.F. \& M.N. Hosen. (2013). Efisiensi Bank Umum Syariah Menggunakan Pendekatan Two-Stage Data Envelopment Analysis. Buletin Ekonomi Moneter dan Perbankan. 16 (2): 168-190.

Hassan, M.K. (2005) The Cost, Profit and X-Efficiency of Islamic Banks, Paper Presented at the 12th ERF Annual Conference, 19th-21st December, Egypt.

Hosen, M.N. \& R. Rahmawati. (2016). Efficiency and Profitability on Indonesian Islamic Banking Industry. Al-Iqtishad: Jurnal Ilmu Ekonomi Syariah (Journal of Islamic Economics). 8 (1): 33-48.

Huda, N. \& M.E. Nasution. (2014). Current Issues Lembaga Keuangan Syariah (ed.ke2). Jakarta: Kencana.

Huri, M.D. \& I. Susilowati. (2004). Pengukuran Efisiensi Relative Emiten Dengan Metode Data Envelopment Analysis (DEA):Studi Kasus Bank-Bank Yang Terdaftar Di Bursa Efek Jakarta 2002. Jurnal Dinamika Pembangunan. Vol 1 No 02: 95-110.

Ilyana, U. (2014). Efisiensi Perbankan Syariah di Indonesia dan Faktor-Faktor Yang Mempengaruhinya. (Tesis Tidak dipublikasikan). Yogyakarta: Universitas Islam Indonesia.

Ismail, F., M.S. Majid., Rahim. Rossana AB. (2013). Efficiency of Islamic and Conventional Banks in Malaysia. Journal of Financial Reporting and Accounting. Vol. 11 (1): 92-107.

Muizuddin \& Iznurhadi. (2012). Efisiensi Perbankan Syariah di Indonesia: Two-Stage Data Envelopment Analysis Approach. E-Journal Universitas Sriwijaya Palembang, 1-16. 
Ningsih, W.W. (2012). Analisis Perbandingan Kinerja Keuangan Bank Umum Syariah Dengan Bank Umum Konvensional di Indonesia. (Skripsi Tidak Dipublikasikan). Makassar: Universitas Hasanuddin

Noor, V.S.D.E.P. (2013). Analisis Perbandingan Efisiensi Bank Syariah dan Bank Konvensional Dengan Menggunakan Metode Data Envelopment Analysis (DEA). (Skripsi Tidak Dipublikasikan). Jakarta: UIN Syarif Hidayatullah.

Perwitaningtyas, G.A. (2014), Faktor-Faktor yang Mempengaruhi Efisiensi Bank di Indonesia Periode Tahun 2008-2012. (Skripsi Tidak Dipublikasikan). Semarang: Fakultas Ekonomika dan Bisnis Universistas Diponegoro.

Pratikto, H \& I. Sugianto. (2011). Kinerja Efisiensi Bank Syariah Sebelum dan Sesudah Krisis Global Berdasarkan Data Envelopment Analysis. Jurnal Ekonomi Bisnis. 16 (2): 108-117.

Rahman, A.R \& R. Rosman. (2013). Efficiency of Islamic Banks: A Comparative Analysis of MENA and Asian Countries. Journal of Economic Cooperation and Development. 34 (1): 63-92.

Rodoni, A., M.A. Salim, E. Amalia \& R.S. Rakhmadi. (2017). Comparing Efficiency and Productivity in Islamic Banking: Case Study in Indonesia, Malaysia, and Pakistan. Al-Iqtishad: Jurnal Ilmu Ekonomi Syariah Uournal of Islamic Economics). 9 (2): 227-242.

Sari, N. (2010). Analisis Tingkat Efisiensi Perbankan Syariah dan Faktor Internal Eksternal Yang Mempengaruhinya. (Skripsi tidak dipublikasikan). Jakarta: UIN Syarif Hidayatullah.

Sarjono, J. (2008). Analisa Efisiensi Bank Umum Syariah Di Indonesia Dengan Metode Data Envelopment Analisis (Studi Kasus Pada Bank Muamalat Indonesia, Bank Syariah Mandiri dan Bank Mega Syariah Tahun 2005 Sampai 2010). (Skripsi Tidak Dipublikasikan). Yogyakarta: UIN Sunan Kalijaga.

Setiawan, A. (2013). Analisis Perbandingan Efisiensi Bank Konvensional dan Bank Syariah Dengan Menggunakan Metode Data Envelopment analysis (DEA) (Periode 2008-2012). (Skripsi Tidak Dipublikasikan). Jakarta: UIN Syarif Hidayatullah. 
Shahid, H., R. Ramizur, S.K.N. Ghulam, \& Raoof A. (2010). Effeciencies Comparison of Islamic Banking and Conventional Banks of Pakistan. International Research Journal of Finance and Economics. 49: 24-42.

Siringoringo, R. (2012). Karakteristik dan Fungsi Intermediasi Perbankan di Indonesia. Buletin Ekonomi Moneter dan Perbankan, 15 (1): 61-83.

Soetanto, T.V. \& Ricky. (2011). Technical Efficiency of Indonesian Commercial Banks: An Application of Two- Stage DEA. Jurnal Manajemen dan Kewirausahaan. vol.13 (2): 107-116.

Widyastuti, N. (2011). Analisis Pengaruh Asset, Dana Pihak Ketiga, dan Kredit yang diberikan Terhadap Kinerja Efisiensi Bank Persero di Indonesia. (Skripsi Tidak Dipublikasikan). Jakarta: Fakultas Ekonomi dan Bisnis UIN Syarif Hidayatullah.

Yulita, I. \& S. Rizal. (2016). Islamic Banking Efficiency: Comparative Study Between Malaysia and Indonesia. Signifikan: Jurnal Ilmu Ekonomi. 5 (1): 31-50. 